February 2005 • NREL/CP-520-37374

\title{
Diamond-Like Carbon Coatings as Encapsulants for Photovoltaic Solar Cells
}

F.J. Pern and K. Touryan

National Renewable Energy Laboratory

Zh. Panosyan

The State Engineering University of Armenia

A.A. Gippius

P.N. Lebedev Physical Institute of the Russian Academy of Science

J.A. Kontsevoy

Pulsar Institute

Prepared for the $31^{\text {st }}$ IEEE Photovoltaic Specialists Conference and Exhibition

Lake Buena Vista, Florida

January 3-7, 2005
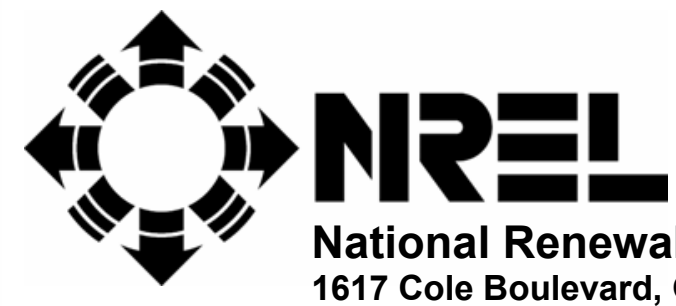

National Renewable Energy Laboratory

1617 Cole Boulevard, Golden, Colorado 80401-3393

303-275-3000 • www.nrel.gov

Operated for the U.S. Department of Energy

Office of Energy Efficiency and Renewable Energy

by Midwest Research Institute $\bullet$ Battelle

Contract No. DE-AC36-99-G010337 


\section{NOTICE}

The submitted manuscript has been offered by an employee of the Midwest Research Institute (MRI), a contractor of the US Government under Contract No. DE-AC36-99G010337. Accordingly, the US Government and MRI retain a nonexclusive royalty-free license to publish or reproduce the published form of this contribution, or allow others to do so, for US Government purposes.

This report was prepared as an account of work sponsored by an agency of the United States government. Neither the United States government nor any agency thereof, nor any of their employees, makes any warranty, express or implied, or assumes any legal liability or responsibility for the accuracy, completeness, or usefulness of any information, apparatus, product, or process disclosed, or represents that its use would not infringe privately owned rights. Reference herein to any specific commercial product, process, or service by trade name, trademark, manufacturer, or otherwise does not necessarily constitute or imply its endorsement, recommendation, or favoring by the United States government or any agency thereof. The views and opinions of authors expressed herein do not necessarily state or reflect those of the United States government or any agency thereof.

Available electronically at http://www.osti.gov/bridge

Available for a processing fee to U.S. Department of Energy and its contractors, in paper, from:

U.S. Department of Energy

Office of Scientific and Technical Information

P.O. Box 62

Oak Ridge, TN 37831-0062

phone: 865.576 .8401

fax: 865.576.5728

email: mailto:reports@adonis.osti.gov

Available for sale to the public, in paper, from:

U.S. Department of Commerce

National Technical Information Service

5285 Port Royal Road

Springfield, VA 22161

phone: 800.553 .6847

fax: 703.605.6900

email: orders@ntis.fedworld.gov

online ordering: http://www.ntis.gov/ordering.htm 


\title{
DIAMOND-LIKE CARBON COATINGS AS ENCAPSULANTS FOR PHOTOVOLTAIC SOLAR CELLS
}

\author{
F.J. Pern, ${ }^{1}$ Zh. Panosyan, ${ }^{2}$ A.A. Gippius, ${ }^{3}$ J.A. Kontsevoy, ${ }^{4}$ K. Touryan, ${ }^{1}$ S. Voskanyan, ${ }^{2}$ and Y. Yengibaryan ${ }^{2}$ \\ 1 National Renewable Energy Laboratory (NREL), 1617 Cole Blvd., Golden, CO 80401 \\ 2 Department of Physics, the State Engineering University of Armenia, Yereven, Armenia \\ 3 P. N. Lebedev Physical Institute of the Russian Academy of Sciences, Moscow, Russia \\ 4 "Pulsar" Institute, Moscow, Russia
}

\begin{abstract}
High-quality single layer and bilayer diamond-like carbon (DLC) thin films are fabricated by two technologies, namely, ion-assisted plasma-enhanced deposition (IAPED) and electron cyclotron resonance (ECR) deposition. Deposition on various substrates such as sapphires and solar cells has been performed at low substrate temperatures $\left(50^{\circ} \sim 80^{\circ} \mathrm{C}\right)$. The two deposition technologies allow good control over the growth conditions to produce DLC films with desired optical properties, thickness, and energy bandgap. The bilayer structured DLC can be fabricated by using IAPED for the bottom layer followed by ECR for the top layer, or just by IAPED for both layers with different compositions. The DLC films have shown good spatial uniformity, density, microhardness, and adhesion strength. They exhibit excellent stability against attack by strong acids, prolonged damp-heat exposure at $85^{\circ} \mathrm{C}$ and $85 \%$ relative humidity, mechanical scratch, ultrasonication, and irradiation by ultraviolet (UV), protons, and electrons. When deposited on crystalline Si and GaAs solar cells in single layer and/or bilayer structure, the DLC films not only serve as antireflection coating and protective encapsulant, but also improve the cell efficiencies.
\end{abstract}

\section{INTRODUCTION}

Diamond-like carbon (DLC) coatings have received increasing attention in the past decade for their unique physical and electrical properties. They may have great potential in various applications, as reviewed independently by Lifshitz [1] and Grill [2] in 1999. For example, Park and Chin employed DLC to protect polycarbonate sheets from radiation-induced degradation [3]. Litovchenko and Klyui demonstrated that crystalline-Si (c-Si) solar cells deposited with N-doped DLC films by the r.f. glow-discharge method are useful for space applications [4]. Applebaum et al. investigated the electron-damaging effects on DLC-coated c-Si solar cells [5]. For DLC coatings to be practically useful for space or terrestrial solar cells, two issues have to be resolved. The first issue is the potential reflection loss resulting from the large refractive index of the DLC coatings, and the second issue is the need to resist the irradiation encountered in space. These issues are addressed in this project by using a bilayer structure of DLC coatings. In this design, the refractive index, energy bandgap, and thickness of the two DLC layers are the key factors that require good control in film growth. The first (bottom) DLC layer, adjacent to the $p-n$ junction of a solar cell, should meet the conditions of antireflection and be thin enough that the requirements for the energy bandgap can be relaxed. This, in turn, can minimize the transmission loss. The second (top) DLC layer should have a lower refractive index to minimize reflection losses at the surface of the structure, a large energy bandgap to minimize absorption loss, and a thickness large enough to provide adequate radiationstopping power. This project has focused on the developments of two DLC deposition technologies for single layer and bilayer DLC films with controllable energy bandgap and refractive index. The effect of deposition conditions, different gas mixtures, physical properties, and the ability of the DLC films to withstand weathering including UV, electron, and proton irradiations, are studied. The developed deposition technologies and related parameter controls have been successfully employed to produce high-quality DLC films serving as both antireflectance coatings and protective encapsulants for c$\mathrm{Si}$ and GaAs solar cells. These coatings also enhance cell efficiencies.

\section{EXPERIMENTAL}

IAPED is the main technique developed in this project for the growth of DLC films [6-8], The Kashtan IAPED system, manufactured by the S. A. Vekshinsky Institute of Vacuum Technique, uses a reaction chamber that is modified with a radical ion source to initiate decomposition of hydrocarbons. The ion source with a cold cathode provides ionization of the gas by means of electron impact. The feed-gas mixture (e.g., $\mathrm{C}_{7} \mathrm{H}_{8}, \mathrm{Ar}, \mathrm{N}_{2}$ ) consisted of $55 \% \mathrm{Ar}$, with the remaining $45 \%$ divided between $\mathrm{C}_{7} \mathrm{H}_{8}$ and $\mathrm{N}_{2}$. The DLC films were grown typically with ion energy between 20 and $140 \mathrm{eV}$, because ion energy higher than $140 \mathrm{eV}$ would degrade solar cell properties and ion energy lower than $20 \mathrm{eV}$ would produce films with refractive index too high to be useful for antireflection coatings. Plasma current was between 0.20 
and $0.80 \mathrm{~mA} / \mathrm{cm}^{2}$ to ensure proper deposition efficiency and reduce defects in the DLC films. A specially designed substrate holder with a complex rotating capability allowed film nonuniformity of less than $5 \%$ within an area $\geq 110$ $\mathrm{cm}^{2}$ at relatively low deposition temperatures $\left(50^{\circ} \sim 80^{\circ} \mathrm{C}\right)$. The other technique developed for DLC film growth is ECR deposition using a custom-built system. In this technique, the strength of the applied magnetic field is selected so that the resulting frequency of electron gyration is equal to that of the microwave frequency. When the two frequencies are matched, the plasma density is dramatically increased by the enhanced absorption of microwave energy by the plasma. Single layer DLC films from either method and bilayer films from subsequent depositions first by IAPED and then by ECR were prepared. The DLC films were characterized for their transmission, reflectance, Raman, adhesion strength, morphology, and resistance to strong acids, damp-heat exposure, and irradiations of UV, electrons, and protons.

\section{RESULTS AND DISCUSSION}

As stated in the Introduction, two issues have to be resolved for the DLC films to be practically useful for space or terrestrial solar cells: (1) the potential reflection loss resulting from the large refractive index of the DLC coating and (2) the resistance to the irradiation in space. These issues are addressed in this project by using a bilayer structure of DLC coatings as shown in Fig. 1. The first layer (adjacent to the p-n junction of the PV cell) should possess the properties that meet the conditions of antireflection, that is

$$
\begin{aligned}
& n_{D L C(1)}=\sqrt{n_{D L C(2)}} \cdot \sqrt{n_{S i}} \\
& d_{D L C(1)}=\lambda / 4 n_{D L C(1)},
\end{aligned}
$$

and

where $\lambda$ is the wavelength corresponding to maximal antireflection, and $\mathrm{n}_{D L C(1)}$ and $\mathrm{N}_{\mathrm{DLC}(2)}$ are the refractive indexes of the two DLC layers.

Accordingly, the bottom layer ( $\mathrm{DLC}_{1}$ ) should possess a high refractive index and a thickness of $60 \sim 80 \mathrm{~nm}$. The minimal thickness of this layer makes the requirements for the energy bandgap less severe than those for the second layer. The top layer $\left(\mathrm{DLC}_{2}\right)$ should possess a low

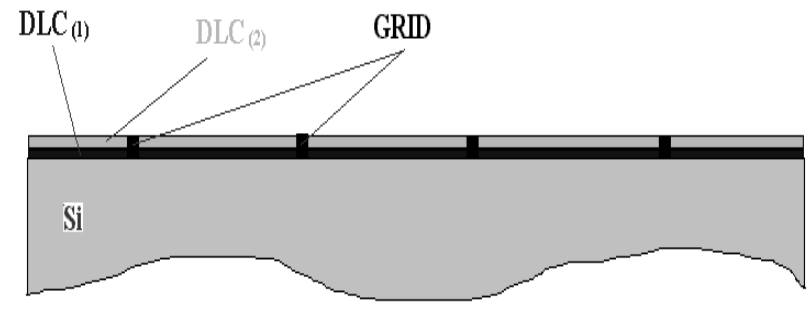

Fig. 1. Cross-section of $P V$ cell with contact grid and bilayer DLC film encapsulant.

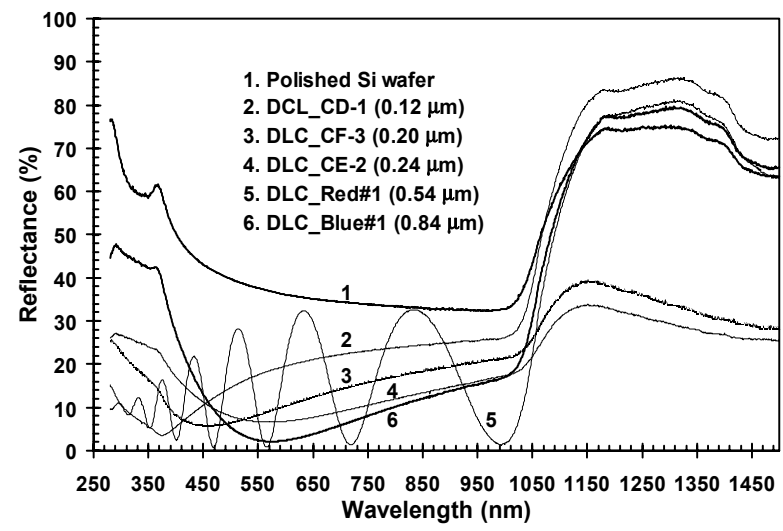

Fig. 2. Reflectance spectra of single layer DLC films of various thickness deposited by IAPED on crystalline-Si wafers.

refractive index to minimize reflection losses at the surface of the structure with a large energy bandgap to minimize absorption losses and a thickness high enough to provide adequate resistance to radiation. The bilayer-structured DLC can be fabricated by using IAPED for the bottom (first) layer followed by ECR for the top (second) layer, or just by IAPED with different compositions for both layers.

Optically, the DLC film's thickness affected its transmittance (not shown) and reflectance spectra. The latter is illustrated in Fig. 2 for some DLC films of various thicknesses deposited on $\mathrm{Si}$ substrates by IAPED. As seen, optimal reduction in reflectance loss can be obtained with adequate film thickness. Table 1 illustrates the effects of deposition conditions, concentration of $\mathrm{C}_{7} \mathrm{H}_{8}$,

Table 1. Refractive indexes ( $n$ ) and thickness (d) of DLC films grown by IAPED using $\mathrm{C}_{7} \mathrm{H}_{8}$ deposited under various conditions of anode-cathode voltage, $\mathrm{U}_{\mathrm{ac}}$, current density, bias voltage, $\mathrm{U}_{\mathrm{b}}$, and average ion kinetic energy, $\left\langle\mathrm{E}_{\mathrm{k}}\right\rangle$.

\begin{tabular}{|cccccccccc|}
\hline $\begin{array}{c}\text { No. of } \mathbf{S i} \\
\text { sample }\end{array}$ & $\begin{array}{c}\mathbf{U}_{\mathbf{a c}} \\
(\mathbf{k V})\end{array}$ & $\begin{array}{c}\mathbf{I}_{\mathbf{a c}} \\
(\mathbf{m A})\end{array}$ & $\begin{array}{c}\mathbf{J}_{\mathbf{p}} \\
\left(\mathbf{m A} / \mathbf{c m}^{2}\right)\end{array}$ & $\begin{array}{c}\mathbf{U}_{\mathbf{b}} \\
\mathbf{( V )}\end{array}$ & $\begin{array}{c}\text { Pressure } \\
(\mathbf{p a s c a l})\end{array}$ & $\begin{array}{c}\mathbf{C}_{\mathbf{7}} \mathbf{H}_{\mathbf{8}} \\
(\mathbf{\%})\end{array}$ & $\begin{array}{c}\left\langle\mathrm{E}_{\mathbf{k}}\right\rangle \\
(\mathbf{e V})\end{array}$ & $\begin{array}{c}\text { Thickness } \\
\mathbf{d}(\mathbf{n m})\end{array}$ & $\begin{array}{c}\mathbf{R} . \mathbf{I} \mathbf{n} \\
\mathbf{n}\end{array}$ \\
\hline 85 & 2.5 & 30 & 0.20 & -300 & $4 \times 10^{-3}$ & 35 & 90 & 240 & 1.48 \\
78 & 2.6 & 35 & 0.25 & -350 & $6 \times 10^{-3}$ & 28 & 100 & 250 & 2.00 \\
79 & 2.8 & 40 & 0.30 & -400 & $8 \times 10^{-3}$ & 24 & 140 & 290 & 2.10 \\
86 & 2.2 & 80 & 0.60 & -250 & $9 \times 10^{-3}$ & 18 & 60 & 185 & 2.40 \\
95 & 2.3 & 100 & 0.65 & -300 & $1 \times 10^{-2}$ & 12 & 65 & 196 & 2.45 \\
93 & 2.4 & 120 & 0.80 & -350 & $3 \times 10^{-2}$ & 15 & 70 & 200 & 2.35 \\
99 & 1.5 & 45 & 0.35 & -20 & $2 \times 10^{-2}$ & 10 & 20 & 194 & 2.55 \\
98 & 1.8 & 50 & 0.40 & -50 & $5 \times 10^{-2}$ & 8 & 25 & 192 & 2.60 \\
91 & 2.0 & 60 & 0.45 & -100 & $7 \times 10^{-2}$ & 4 & 35 & 190 & 2.57 \\
\hline
\end{tabular}


and film thickness on the refractive index, $n$, of DLC films deposited by IAPED on monocrystalline Si wafers. These results clearly demonstrate that, by controlling the various parameters, either single layer or bilayer DLC films of continuously varying compositions can be conveniently grown by the IAPED method. On the other hand, using different reactant species, from ketones to alcohols, DLC films of different energy bandgaps, $2.4 \mathrm{eV}<\mathrm{E}_{\mathrm{bg}}<3.0 \mathrm{eV}$, and refractive indexes, $1.54<\mathrm{n}<2.05$, were obtained by the ECR method, as shown in Table 2.

Results of Raman shift analysis for these films in Fig. 3 show a broad emission peak centered at $\sim 1535 \mathrm{~cm}^{-1}$ compared to the sharp peak at $1332 \mathrm{~cm}^{-1}$ for $\mathrm{sp}^{3}$ of a pure diamond, confirming that the DLC films are primarily amorphous, but with a predominant characteristic of $\mathrm{sp}^{3}$. An increase in the cell efficiency on $\mathrm{c}-\mathrm{Si}$ and GaAs solar cells was obtained when they were coated with DLC films. The current-voltage and power-voltage curves for a c-Si cell before and after a single layer DLC film was deposited is shown in Fig. 4. If the surface of c-Si cell was first cleaned with ions, a higher increase of cell efficiency was obtained with DLC coating (figure not shown). The increase in the cell efficiency was attributed primarily to

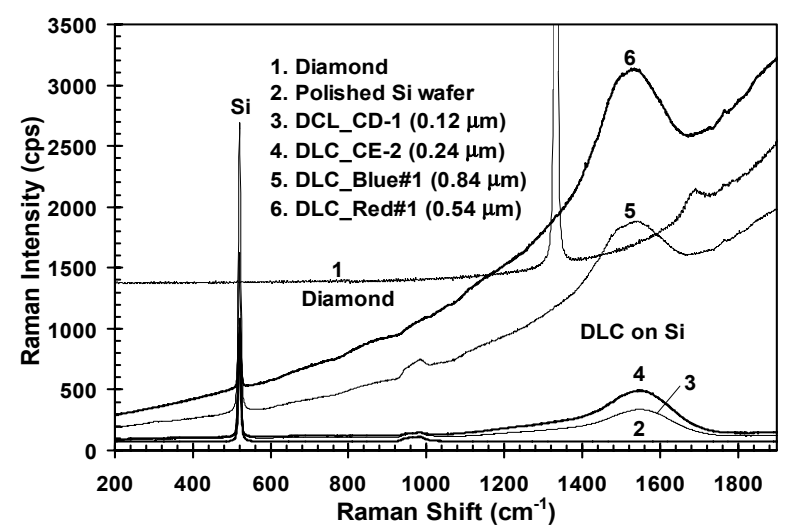

Fig. 3. Raman spectra comparing the DLC deposited on Si wafers as in Fig. 1 with a blank Si wafer and a diamond reference.

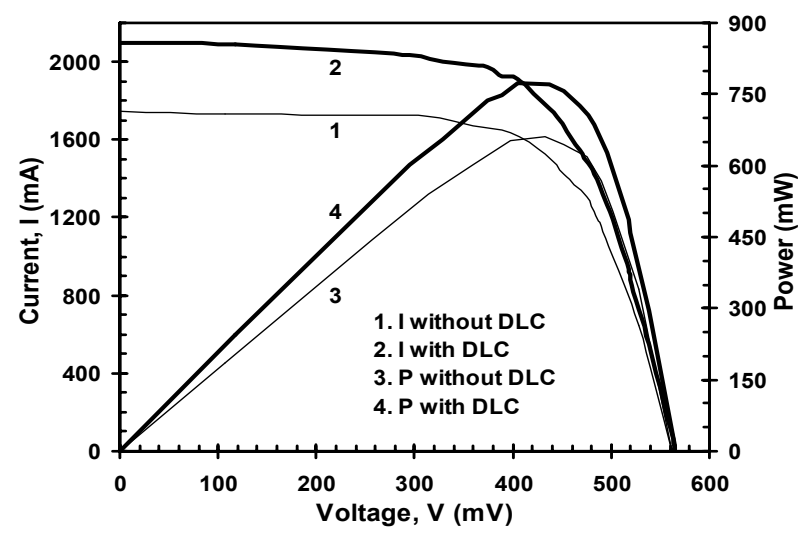

Fig. 4. Current-voltage and power-voltage curves for a $\sim 100-\mathrm{cm}^{2} \mathrm{c}-\mathrm{Si}$ solar cell without $(1,3)$ and with $(2,4)$ a DLC coating by IAPED.
Table 2. Energy gap and refraction index of DLC films grown by ECR technique with various reactant species

\begin{tabular}{|lcc|}
\hline $\begin{array}{l}\text { Reactant } \\
\text { Species }\end{array}$ & $\begin{array}{c}\text { Energy Gap } \\
\mathbf{E}_{\mathbf{b g}}(\mathbf{e V})\end{array}$ & $\begin{array}{c}\text { Refractive } \\
\text { Index, } \mathbf{n}\end{array}$ \\
\hline $\mathrm{CH}_{3} \mathrm{COCH} \mathrm{H}_{3}$ & 2.85 & 1.6 \\
$\mathrm{C}_{2} \mathrm{H}_{5} \mathrm{OC}_{2} \mathrm{H}_{5}$ & 2.65 & 1.65 \\
$\mathrm{CH}_{3} \mathrm{COC}_{2} \mathrm{H}_{5}$ & 2.4 & 1.75 \\
$\mathrm{C}_{2} \mathrm{H}_{5} \mathrm{OH}$ & 2.9 & 1.54 \\
$\mathrm{C}_{4} \mathrm{H}_{9} \mathrm{OH}$ & 2.5 & 2.05 \\
$\mathrm{CH}_{3} \mathrm{OH}$ & 3.0 & 1.54 \\
$\mathrm{C}_{3} \mathrm{H}_{7} \mathrm{OH}$ & 3.0 & 1.6 \\
\hline
\end{tabular}

Table 3. Cell parameters for a GaAs solar cell without and with DLC coating (DLC ${ }_{1}$ layer by IAPED, $60 \mathrm{~nm}$ thick; $\mathrm{DLC}_{2}$ layer by ECD, $900 \mathrm{~nm}$ thick)

\begin{tabular}{|c|c|c|c|c|c|}
\hline $\begin{array}{l}\text { Solar Cell } \\
+ \text { Coating }\end{array}$ & $\begin{array}{l}I_{s c} \\
(m A)\end{array}$ & $\begin{array}{l}V_{o c} \\
(\mathrm{mV})\end{array}$ & $\begin{array}{l}I_{\max } \\
(\mathrm{mA})\end{array}$ & $\begin{array}{l}V_{\max } \\
(\mathrm{mV})\end{array}$ & $\begin{array}{l}\text { Eff. } \\
\text { (\%) }\end{array}$ \\
\hline $\begin{array}{l}\text { Original Cell } \\
\text { with ZnS AR }\end{array}$ & 82 & 960 & 76 & 760 & 12.2 \\
\hline $\begin{array}{l}\text { No AR } \\
\text { (ZnS removed) }\end{array}$ & 62 & 940 & 56 & 760 & 9.26 \\
\hline $\mathrm{DLC}_{1}$ & 74 & 960 & 68 & 760 & 11.0 \\
\hline $\mathrm{DLC}_{1}+\mathrm{DLC}_{2}$ & 84 & 960 & 80 & 740 & 12.5 \\
\hline
\end{tabular}

the effect of anti-reflection of the DLC coating, although contribution by reduced surface boundary recombination loss was also possible. For the GaAs cell sample, the efficiency improvements are shown in Table 3. In this case, the first layer DLC coating was applied by IAPED on the GaAs cell whose original ZnS AR coating was removed, resulting in a cell increase from $9.26 \%$ to $11.0 \%$. With second DLC layer deposited by ECR, the cell efficiency increased further to $12.5 \%$, higher than the $12.2 \%$ with ZnS AR coating. This demonstrates the feasibility of depositing bilayer-structured DLC coating by the two deposition technologies. The bilayer-structured DLC coating was also fabricated by using IAPED method with continuous composition gradient. The DLC coatings have also been applied successfully to thin-film amorphous $\mathrm{Si}$ cells and mini-modules. These results will be presented elsewhere.

The DLC films were very resistant to the attacks of high humidity at high temperature and mineral acids such as $\mathrm{HCl}, \mathrm{HNO}_{3}$, and $\mathrm{H}_{2} \mathrm{SO}_{4}$, as demonstrated in Table 4 for Si cells with DLC coatings. In comparison, $\mathrm{ZnS}$ is easily attacked by mineral acids. The DLC films on Si wafers showed virtually no change in reflectance after $762 \mathrm{~h}$ of damp-heat exposure at $85^{\circ} \mathrm{C}$ and $85 \%$ relative humidity $(\mathrm{RH})$. The DLC films deposited on Si wafer or cell were very resistant to mechanical scratch and ultrasonication tests, no scratch-off or peel-off was observed. They also exhibited excellent stabilities against UV, proton, and electron irradiations, as illustrated in Figs. 5 and 6 , showing very little change in the spectral efficiency of $\mathrm{Si}$ cells when protected by $1.5-\mu \mathrm{m}$ DLC films (Fig. 5) and small change in the transmittance spectrum of $0.51-\mu \mathrm{m}$ DLC films on sapphire (Fig. 6) before and after irradiation by protons and electrons, respectively. 
Table 4. Efficiencies of c-Si PV cells with DLC films grown at various conditions before and after weathering at $80^{\circ}-90^{\circ} \mathrm{C}$ and $90 \% \mathrm{RH}$ for $20 \mathrm{~h}$ (W.T.) and chemical stability tests* (C.T.)

\begin{tabular}{|lllllll|}
\hline $\begin{array}{l}\text { Cell } \\
\text { ID }\end{array}$ & $\begin{array}{l}<E k> \\
(\mathbf{e V})\end{array}$ & $\begin{array}{l}\mathbf{C}_{7} \mathbf{H}_{8} \\
(\%)\end{array}$ & $\begin{array}{l}\mathbf{d} \\
(\mathbf{n m})\end{array}$ & \multicolumn{3}{c|}{ Cell Efficiency (\%) } \\
Initial & $\begin{array}{l}\text { After } \\
\text { W.T. }\end{array}$ & $\begin{array}{l}\text { After } \\
\text { C.T. }\end{array}$ \\
\hline 30 & 55 & 22 & 80 & 9.87 & 9.85 & 9.78 \\
41 & 70 & 16 & 80 & 9.71 & 9.75 & 9.58 \\
42 & 65 & 13 & 75 & 8.90 & 8.93 & 8.78 \\
43 & 60 & 12 & 85 & 9.27 & 9.23 & 9.28 \\
44 & 75 & 10 & 85 & 9.11 & 9.18 & 9.14 \\
45 & 65 & 14 & 80 & 8.82 & 8.90 & 8.80 \\
\hline
\end{tabular}

* Chemical stability tests included sequentially:

1. concentrated $\mathrm{HNO}_{3}$ acid, $30 \mathrm{~min}, 25^{\circ} \mathrm{C}$

2. diluted $(1 \%) \mathrm{HNO}_{3}$ acid, $1 \mathrm{~h}, 25^{\circ} \mathrm{C}$

3. concentrated $\mathrm{H}_{2} \mathrm{SO}_{4}$ acid, $30 \mathrm{~min}, 25^{\circ} \mathrm{C}$

4. diluted $(1 \%) \mathrm{H}_{2} \mathrm{SO}_{4}$ acid, $1 \mathrm{~h}, 25^{\circ} \mathrm{C}$

5. saturated solution of $\mathrm{NaCl}$ (sea fog simulation), 40 h, $25^{\circ}-30^{\circ} \mathrm{C}$

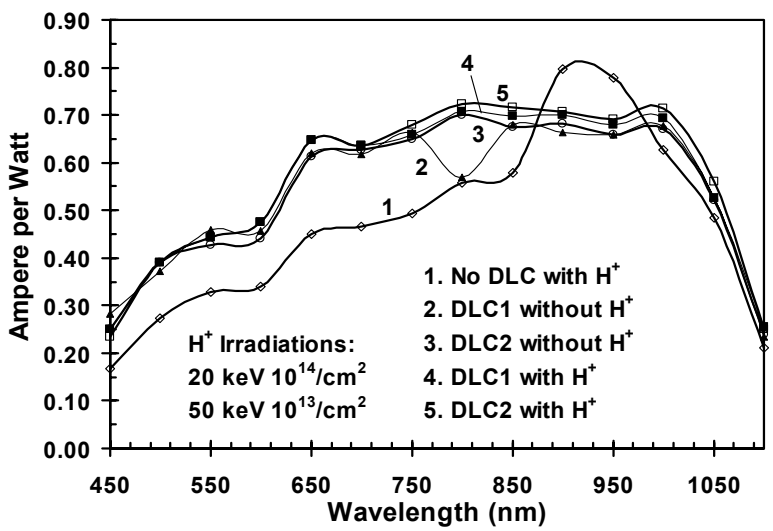

Fig. 5. Spectral efficiency of three Si PV cells without and with 1.5- $\mu \mathrm{m}$ DLC coating exposed to two levels of proton irradiation, $10^{14} / \mathrm{cm}^{2} 20 \mathrm{keV}$ and $10^{13} / \mathrm{cm}^{2} 150$

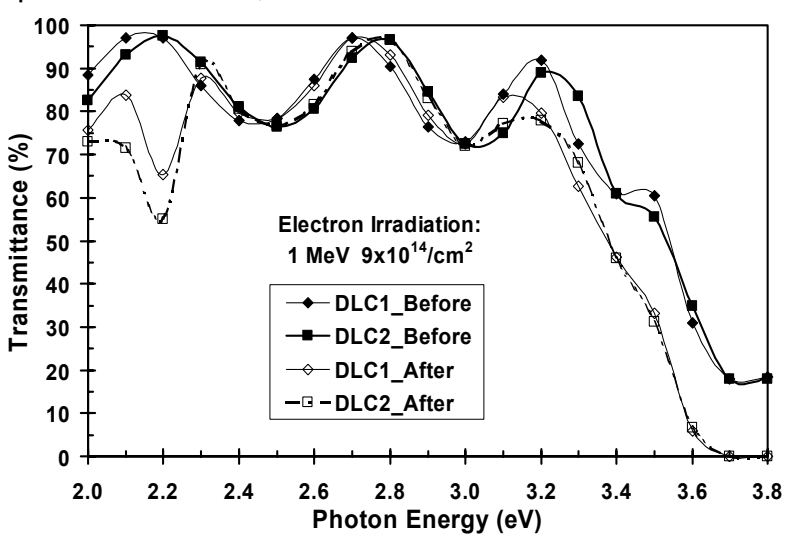

Fig. 6. Transmission spectra of two 0.51- $\mu \mathrm{m}$ DLC films on sapphire substrates before and after irradiation by $9 \times 10^{14} / \mathrm{cm}^{2} 1-\mathrm{MeV}$ electrons.

\section{CONCLUSIONS}

High-quality DLC films were obtained using ionassisted plasma-enhanced and electron cyclotron resonance deposition technologies. The two technologies allowed DLC film fabrications at low temperatures with good spatial uniformity. Single and bilayer DLC films were obtained with good control of the deposition parameters and feed-gas mixture for desired transmittance, reflectance, thickness, and refractive index that can be fine-tuned in the range of 1.5 2.6, and an energy bandgap of up to $4.0 \mathrm{eV}$. The DLC films, when deposited on crystalline $\mathrm{Si}$ wafers, have shown excellent stability against mineral acids and prolonged damp heat exposure, high adhesion strength, and excellent stability against irradiations. Serving as both an antireflection coating and a protective encapsulant, the DLC films enhanced the efficiency of c-Si and GaAs solar cells.

\section{ACKNOWLEDGEMENTS}

The authors thank Drs. M.-J. Seong and S.-J. Yoon at NREL for the Raman characterization. This work was supported by the U.S. Department of Energy under the Initiatives for Proliferation Prevention program (IPP) Contract No. AAT-1-31902-01.

\section{REFERENCES}

[1] Y. Lifshitz, "Diamond-Like Carbon-Present Status," Diamond and Related Materials, 8, 1999, pp. 1659-1676.

[2] A. Grill, "Diamond-Like Carbon: State of the Art," ibid., 8, 1999, pp. 428-434.

[3] K.J. Park and E.Y. Chin, "Effect of Diamond-Like Carbon Thin Film Deposition on the Resistance of Polycarbonate to Radiation-Induced Degradation," Polymer Degradation and Stability, 68, 2000, pp. 93-96.

[4] V.G. Litovchenko and N.I. Klyui, "Solar Cells Based on DLC Film - Si Structures for Space Application," Solar Energy Materials and Solar Cells, 68, 2001, pp. 55-70.

[5] J. Applebaum, N. Croitoru, L. Klibanov, and D. Scheinman, "The Effect of Electron Damage on Silicon Solar Cells Coated with Diamond-Like Carbon Films," Prog. Photovolt: Res. Appl., 8, 2000, pp. 571-578.

[6] K. Kassabian, Zh. Panosyan, A. Stepanyan, G. Torosyan, and Y. Yengibaryan, "Low-Temperature Technology of Obtaining the Protecting Layer From Diamond-Like Film," Proceeding of the 6th Applied Diamond Conference, Auburn, Alabama, USA, 2001, pp. 431-435.

[7] Y. Yengibaryan, S. Voskanyan, A. Voskanyan, A. Stepanyan, and Zh. Panosyan, "Growth of Diamond-Like Carbon Films on the Si Surface of Solar Cell." Proceeding of the 3rd National Conference of "Semiconductor Microelectronics," Sevan, 2001, pp. 267-271.

[8] Y.A. Kontsevoy, P.B. Constantinov, and S.L. Shevchuk, "Studies of DLC films Grown with Ion Beam Technique." Russian Conference on "Micro- and Nanoelectronics - 2001," Zvenigorod, 2001, p. 44. 


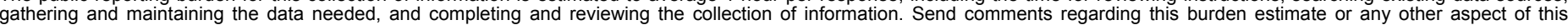

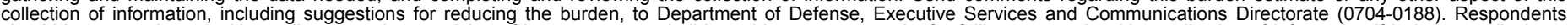

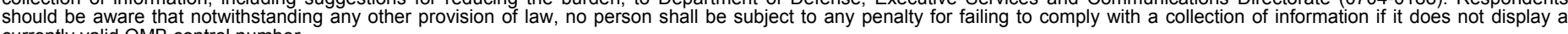

PLEASE DO NOT RETURN YOUR FORM TO THE ABOVE ORGANIZATION.

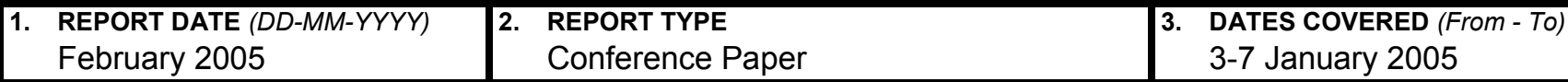

4. TITLE AND SUBTITLE

Diamond-Like Carbon Coatings as Encapsulants for Photovoltaic Solar Cells 5a. CONTRACT NUMBER

DE-AC36-99-GO10337

5b. GRANT NUMBER

5c. PROGRAM ELEMENT NUMBER

5d. PROJECT NUMBER

NREL/CP-520-37374

5e. TASK NUMBER

DO890210

5f. WORK UNIT NUMBER
7. PERFORMING ORGANIZATION NAME(S) AND ADDRESS(ES)

National Renewable Energy Laboratory, 1617 Cole Blvd., Golden, CO

Department of Physics, the State Engineering University of Armenia,

Yereven, Armenia

P. N. Lebedev Physical Institute of the Russian Academy of Sciences,

Moscow, Russia

Pulsar Institute, Moscow, Russia

9. SPONSORING/MONITORING AGENCY NAME(S) AND ADDRESS(ES)
8. PERFORMING ORGANIZATION

REPORT NUMBER

NREL/CP-520-37374
10. SPONSOR/MONITOR'S ACRONYM(S) NREL

11. SPONSORING/MONITORING AGENCY REPORT NUMBER

12. DISTRIBUTION AVAILABILITY STATEMENT

National Technical Information Service

U.S. Department of Commerce

5285 Port Royal Road

Springfield, VA 22161

13. SUPPLEMENTARY NOTES

\section{ABSTRACT (Maximum 200 Words)}

High-quality single-layer and bilayer diamond-like carbon (DLC) thin films are fabricated by two technologies, namely, ion-assisted plasma-enhanced deposition (IAPED) and electron cyclotron resonance (ECR) deposition. Deposition on various substrates, such as sapphires and solar cells, has been performed at low substrate temperatures $\left(50^{\circ} \sim 80^{\circ} \mathrm{C}\right)$. The two deposition technologies allow good control over the growth conditions to produce DLC films with desired optical properties, thickness, and energy bandgap. The bilayer-structured DLC can be fabricated by using IAPED for the bottom layer followed by ECR for the top layer, or just by IAPED for both layers with different compositions. The DLC films have shown good spatial uniformity, density, microhardness, and adhesion strength. They exhibit excellent stability against attack by strong acids, prolonged damp-heat exposure at $85^{\circ} \mathrm{C}$ and $85 \%$ relative humidity, mechanical scratch, ultrasonication, and irradiation by ultraviolet (UV), protons, and electrons. When deposited on crystalline Si and GaAs solar cells in single-layer and/or bilayer structure, the DLC films not only serve as antireflection coating and protective encapsulant, but also improve the cell efficiencies.

\section{SUBJECT TERMS}

PV; diamond-like carbon (DLC); thin films; ion-assisted plasma-enhanced deposition (IAPED); electron cyclotron resonance (ECR); ultraviolet (UV); antireflection coating; protective encapsulant;

\begin{tabular}{|c|c|c|}
\hline $\begin{array}{l}\text { a. REPORT } \\
\text { Unclassified }\end{array}$ & $\begin{array}{l}\text { b. ABSTRACT } \\
\text { Unclassified }\end{array}$ & $\begin{array}{l}\text { c. THIS PAGE } \\
\text { Unclassified }\end{array}$ \\
\hline
\end{tabular}

\begin{tabular}{l|l} 
17. LIMITATION \\
OF ABSTRACT \\
UL
\end{tabular}

19a. NAME OF RESPONSIBLE PERSON

19b. TELEPHONE NUMBER (Include area code) 